\title{
REACTION OF 3-CYANOCHROMONES WITH PYRIDINIUM PHENACYLIDE
}

\author{
M. Yu. Kornev ${ }^{1}$, V. S. Moshkin ${ }^{1}$, O. S. El'tsov ${ }^{1}$, and V. Ya. Sosnovskikh ${ }^{1 *}$
}

Keywords: betaines, 3-cyanochromones, pyridinium phenacylide, nucleophilic 1,4-addition.

The reaction of 3-cyanochromones with $N$ - and $C$-nucleophiles begins with an attack at C-2 atom with subsequent opening of the $\gamma$-pyrone ring and recyclization at the $\mathrm{C}=\mathrm{O}$ or $\mathrm{C} \equiv \mathrm{N}$ groups [1-3]. Nucleophilic 1,2-addition at the cyano group usually does not occur [1], while the reactions with aromatic amines [4] and methylenetriphenylphosphorane $\left(\mathrm{Ph}_{3} \mathrm{P}=\mathrm{CH}_{2}\right)$ [5] terminate at the stage of open products 1 and 2. Since the assumption of a number of workers of possible addition of nucleophiles at the cyano group was subsequently shown to be incorrect [1], the reports in the literature on the synthesis of azirines $\mathbf{3 a}, \mathbf{b}$ from the corresponding 3-cyanochromones $\mathbf{4 a}, \mathbf{b}$ and pyridinium phenacylide [6] are cast in doubt and require verification.<smiles>[R]c1ccc(O)c(C(=O)/C(C#N)=C\[AlH2])c1</smiles><smiles>N#C/C(=C\C=[Pb])C(=O)c1ccccc1O</smiles><smiles>[R]c1ccc2occ(C3NC3C(=O)c3ccccc3)c(=O)c2c1</smiles>

We have found that 3-cyanochromone $\mathbf{4 a}$ and 3-cyano-6-methylchromone $\mathbf{4 b}$ react with phenacylpyridinium bromide in the presence of one or two equivalents of potassium carbonate in acetone at reflux over $8 \mathrm{~h}$, analogously to phophorus ylide $\mathrm{Ph}_{3} \mathrm{P}=\mathrm{CH}_{2}$, i.e., through Michael addition of pyridinium phenacylide formed in situ with subsequent opening of the pyrone ring to give highly stable ylides 5a,b in 72$77 \%$ yield. The structure of these ylides was confirmed by IR, ${ }^{1} \mathrm{H}$ NMR, and ${ }^{13} \mathrm{C}$ NMR spectroscopy. Heating ylide 5a at reflux in glacial acetic acid for $2 \mathrm{~h}$ gives the starting 3-cyanochromone $4 \mathbf{a}$. Under conditions described for the preparation of azirines 3a,b using four equivalents of potassium carbonate [6], we isolated only a complex, intractable mixture. Products of addition at the CN group, namely, azirines 3a,b, could not be detected despite variation of the conditions. 1,3-Dipolar cycloaddition at the double bond of the pyrone ring leading to indolizines [7] was also not observed.

The signals in the ${ }^{1} \mathrm{H}$ and ${ }^{13} \mathrm{C}$ NMR spectra were assigned on the basis of $2 \mathrm{D}{ }^{1} \mathrm{H}-{ }^{13} \mathrm{C}$ HSQC, HMBC, and ${ }^{1} \mathrm{H}-{ }^{1} \mathrm{H}$ COSY experiments in the case of betaine 5a. The most informative cross peaks in the $2 \mathrm{D}$ HMBC spectrum in DMSO- $\mathrm{d}_{6}$ are $\mathrm{H}-6^{\prime} / \mathrm{C}-5, \mathrm{H}-3^{\prime} / \mathrm{C}-5, \mathrm{H}-3 / \mathrm{C}-5, \mathrm{H}-3 / \mathrm{C}-4$, and $\mathrm{H}-3 / \mathrm{CN}$. The singlet for H-3 proton is

*To whom correspondence should be addressed, e-mail: vyacheslav.sosnovskikh@usu.ru.

${ }^{1}$ Ural Federal University named after the First President of Russia B. N. Yeltsin, 51 Lenina Ave., Yekaterinburg 620000, Russia.

Translated from Khimiya Geterotsiklicheskikh Soedinenii, No. 10, pp. 1678-1680, October, 2012. Original article submitted September 18, 2012. 
found at $7.85 \mathrm{ppm}$, while the broadened signal for the phenol proton is at 9.80-10.80 ppm. The upfield dublet for H-6' proton points to an absence of intramolecular hydrogen bonding in the salicyloyl fragment, which results in phenyl ring deviation from the molecular plane [4]. The IR spectra of betaines $\mathbf{5 a}, \mathbf{b}$ show absorption bands for the $\mathrm{C} \equiv \mathrm{N}$ group at $2172-2183 \mathrm{~cm}^{-1}$ and two $\mathrm{C}=\mathrm{O}$ groups at $1608-1580 \mathrm{~cm}^{-1}$, indicating extensive delocalization of negative charge (for comparison, this band is at $1661 \mathrm{~cm}^{-1}$ for the chromone $4 \mathrm{a}$ and $1614 \mathrm{~cm}^{-1}$ for the ylide 2 [5]).

The IR spectra were recorded on a Bruker Alpha spectrometer with an ATR attachment (ZnSe crystal). The ${ }^{1} \mathrm{H}$ and ${ }^{13} \mathrm{C}$ NMR spectra were recorded on a Bruker Avance II spectrometer (400 and $100 \mathrm{MHz}$, respectively) in DMSO- $\mathrm{d}_{6}$ with TMS as internal standard. The elemental analysis was carried out on an automatic PE 2400 analyzer. The melting points were determined on an FP 62 instrument.

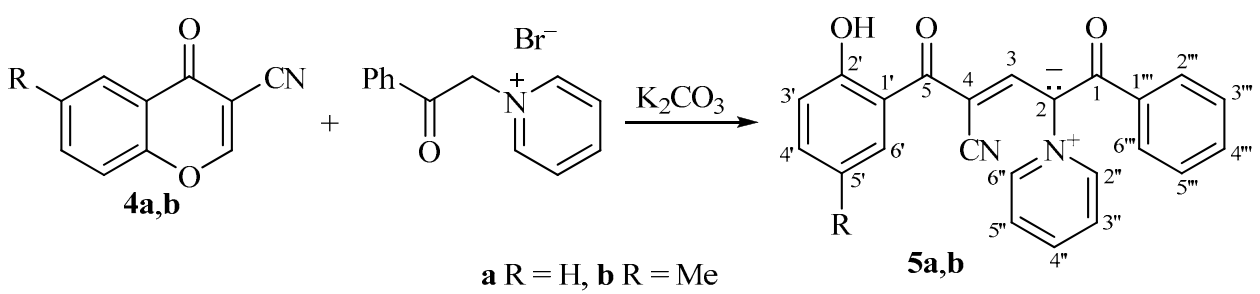

4-Cyano-5-(2-hydroxyphenyl)-1,5-dioxo-2-(pyridinium-1-yl)-1-phenylpent-3-en-2-ide (5a). A mixture of 3-cyanochromone $4 \mathbf{a}(300 \mathrm{mg}, 1.75 \mathrm{mmol})$, phenacylpyridinium bromide (490 $\mathrm{mg}, 1.76 \mathrm{mmol})$, and anhydrous potassium carbonate $(490 \mathrm{mg}, 3.50 \mathrm{mmol})$ in dry acetone $(100 \mathrm{ml})$ was heated at reflux for $8 \mathrm{~h}$. The orange recipitate formed was filtered off, washed with acetone and water, and dried. Yield $480 \mathrm{mg}(72 \%)$. Yellow crystals; mp $215-216^{\circ} \mathrm{C}$ (decomp.). IR spectrum, $v, \mathrm{~cm}^{-1}: 2172,1608,1581,1564,1512,1481 .{ }^{1} \mathrm{H}$ NMR spectrum, $\delta$, $\operatorname{ppm}(J, \mathrm{~Hz}): 6.72\left(1 \mathrm{H}, \mathrm{t}, J=7.5, \mathrm{H}-5^{\prime}\right) ; 6.80\left(1 \mathrm{H}, \mathrm{d}, J=8.2, \mathrm{H}-3^{\prime}\right) ; 7.16\left(1 \mathrm{H}, \mathrm{td}, J=7.6, J=1.5, \mathrm{H}-4{ }^{\prime}\right) ; 7.23(1 \mathrm{H}, \mathrm{d}$, $\left.J=7.5, \mathrm{H}-6^{\prime}\right) ; 7.42-7.57$ (3H, m, H-3"',4"',5"'); 7.58-7.62 (2H, m, H-2"',6"'); 7.85 (1H, s, H-3); 8.23 (2H, t, $J=7.2$, H-3",5"); 8.69 (1H, t, $J=8.0, \mathrm{H}-4 ") ; 9.05$ (2H, d, $J=5.3, \mathrm{H}-2 ", 6 ") ; 9.80-10.80$ (1H, br. s, OH). ${ }^{13} \mathrm{C}$ NMR spectrum, $\delta$, ppm: 116.4 (C-3'); 118.3 (C-5'); $119.0(\mathrm{CN}) ; 121.1$ (C-2); 123.0 (C-4); 125.8 (C-1'); 127.8 (C-3",5"); 128.2 (C-2"',6"'); 128.3 (C-3"',5"'); 128.5 (C-6'); 130.5 (C-4"'); 131.1 (C-4'); 138.5 (C-1"'); 144.0 (C-3); 146.2 (C-4"); 149.1 (C-2",6"); 155.8 (C-2'); 185.8 (C-1); 189.4 (C-5). Found, \%: C 72.82; H 4.34; N 7.34. $\mathrm{C}_{23} \mathrm{H}_{16} \mathrm{~N}_{2} \mathrm{O}_{3} \cdot 0.5 \mathrm{H}_{2} \mathrm{O}$. Calculated, \%: C 73.20; H 4.54; N 7.42.

4-Cyano-5-(2-hydroxy-5-methylphenyl)-1,5-dioxo-1-phenyl-2-(pyridinium-1-yl)pent-3-en-2-ide (5b) was obtained analogously to betaine 5a. Yield $0.88 \mathrm{~g}$ (77\%). Yellow crystals; mp 209-211 ${ }^{\circ} \mathrm{C}$ (decomp.). IR spectrum, $v, \mathrm{~cm}^{-1}: 2183,1605,1580,1564,1514,1494,1473 .{ }^{1} \mathrm{H}$ NMR spectrum, $\delta$, ppm $(J, \mathrm{~Hz}): 2.17(3 \mathrm{H}, \mathrm{s}$, $\left.\mathrm{CH}_{3}\right) ; 6.66\left(1 \mathrm{H}, \mathrm{d}, J=8.2, \mathrm{H}-3^{\prime}\right) ; 6.99\left(1 \mathrm{H}, \mathrm{d}, J=8.2, \mathrm{H}-4^{\prime}\right) ; 7.30(1 \mathrm{H}, \mathrm{s}, \mathrm{H}-6$ '); $7.43-7.53$ (3H, m, H-3"',4"',5'"); 7.62 (2H, d, $J=6.5$, H-2"',6"'); 7.99 (1H, s, H-3); 8.23 (2H, t, $J=6.7, \mathrm{H}-3 ", 5 ") ; 8.68$ (1H, t, $J=7.8, \mathrm{H}-4 ") ; 8.97$ $(2 \mathrm{H}, \mathrm{d}, J=5.3, \mathrm{H}-2 ", 6 ") ; 10.65\left(1 \mathrm{H}\right.$, br. s, OH). Found, \%: C 73.90; H 4.55; N 7.12. $\mathrm{C}_{24} \mathrm{H}_{18} \mathrm{~N}_{2} \mathrm{O}_{3} \cdot 0.5 \mathrm{H}_{2} \mathrm{O}$. Calculated, \%: C 73.64; H 4.89; N 7.16.

This research was carried out with the financial support of young scientists at the Ural Federal University within the development program of this university.

\section{REFERENCES}

1. V. Ya. Sosnovskikh and V. S. Moshkin, Khim. Geterotsikl. Soedin., 144 (2012) [Chem. Heterocycl. Compd., 48, 139 (2012)].

2. P. Langer, Synlett, 1016 (2007).

3. T. Zarganes-Tzitzikas, M. A. Terzidis, J. Stephanidou-Stephanatou, C. A. Tsoleridis, and G. E. Kostakis, J. Org. Chem., 76, 9008 (2011). 
4. V. Ya. Sosnovskikh, V. S. Moshkin, and M. I. Kodess, Izv. Akad. Nauk, Ser. Khim., 602 (2010). [Russ. Chem. Bull., Int. Ed., 59, 615 (2010)].

5. C. D. Gabbutt, B. M. Heron, M. B. Hursthouse, and K. M. Abdul Malik, Phosphorus, Sulfur, Silicon, Relat. Elem., 166, 99 (2000).

6. C. K. Ghosh and S. Sahana, Indian J. Chem., 35B, 203 (1996).

7. I. Yokoe, S. Matsumoto, Y. Shirataki, and M. Komatsu, Heterocycles, 23, 1395 (1985). 